\title{
Science Academies' Summer Research Fellowship Programme for Students and Teachers - 2015
}

\author{
Indian Academy of Sciences, Bangalore \\ Indian National Science Academy, New Delhi \\ The National Academy of Sciences, India, Allahabad
}

The three national science academies offer several two-month Summer Fellowships to enable students/teachers (studying/teaching in India) to work with scientists associated with the three Academies during 2015. A copy of the application format, instructions to applicants including eligibility criteria, and a list of names of scientists/faculty who have consented to guide students/ teachers to work on short-term projects is displayed online.

Applications are invited from interested students and teachers from all universities and colleges affiliated to UGC/AICTE/MCI/Accredited Institutions of State Universities for these Fellowships. The application should include: (a) the application form in the prescribed format; (b) a write-up (in about $150^{-} 250$ words) as to what the applicant wants to learn and achieve; (c) the guide with whom the applicant would like to work. Student applicants should include a recommendation letter from a teacher (in the prescribed format) familiar with their work, in a sealed envelope. The selected candidate may work with the assigned guide for two months any time during the calendar year, preferably during the summer.

Applications should be submitted by logging onto one of our websites [www.ias.ac.in; www.insaindia.org; or www.nasi.org.in]; however, a hard copy of the application together with enclosures must be sent by speed post or courier to The Coordinator, Science Education Panel, Indian Academy of Sciences, CV Raman Avenue, Near Mekhri Circle, Sadashivanagar, Bangalore 560 080. The registration number assigned soon after online submission must be quoted both in the hard copy of the application to be sent and in the letter of recommendation to be forwarded by the teacher in the case of student applicants.

The last date for receipt of applications online is 30 November 2014.

Information of selection along with concurrence of the guide will be despatched around February ${ }^{-}$March 2015. The selected students/teachers will be provided appropriate round trip train fare and a monthly fellowship to meet their living expenses at the place of work.

10 September 2014

Professor K.L. Sebastian

Joint Science Education Panel

Indian Academy of Sciences, Bangalore 